\title{
Enhancing the Sneakers Shopping Experience through Virtual Fitting Using Augmented Reality
}

\author{
Ha-Lim Rhee and Kyu-Hye Lee *[D \\ Human-Tech Convergence Program, Department of Clothing and Textiles, Hanyang University, \\ Seoul 04763, Korea; hadimii@hanyang.ac.kr \\ * Correspondence: khlee@hanyang.ac.kr; Tel.: +82-2-2220-1191
}

Citation: Rhee, H.-L.; Lee, K.-H. Enhancing the Sneakers Shopping Experience through Virtual Fitting Using Augmented Reality. Sustainability 2021, 13, 6336 https: / /doi.org/10.3390/ su13116336

Academic Editor: Abdollah Shafieezadeh

Received: 30 April 2021 Accepted: 29 May 2021 Published: 3 June 2021

Publisher's Note: MDPI stays neutral with regard to jurisdictional claims in published maps and institutional affiliations.

Copyright: (C) 2021 by the authors. Licensee MDPI, Basel, Switzerland. This article is an open access article distributed under the terms and conditions of the Creative Commons Attribution (CC BY) license (https:// creativecommons.org/licenses/by/ $4.0 /)$.

\begin{abstract}
The fashion industry is undergoing a digital transformation due to the emergence of new shopping channels and external factors such as the COVID-19 pandemic. This study examined the relationship between virtual fitting (VF) experience satisfaction, brand advocacy, mobile purchase intention, and offline purchase intention from an omnichannel perspective to understand how VF based on augmented reality (AR) impacts the customer purchase journey. The study also investigated the moderating effect of a customer's product involvement, which is a personal characteristic. The results reveal that high satisfaction with the VF experience had a positive effect only on mobile purchase intentions. Brand advocacy formed after the VF experience had a positive effect on both mobile and offline purchase intentions and showed a mediating effect in the relationship between VF experience satisfaction and purchase intention. The moderating effect of product involvement was also confirmed. Moreover, a significantly negative influence of VF experience satisfaction on offline purchase intention was detected for customers who were more involved in sneakers products. These results indicate that $\mathrm{VF}$, which is used as a tool in shopping apps, can achieve customer satisfaction and drive mobile purchases, thus leading to offline purchases based on brand advocacy.
\end{abstract}

Keywords: sneakers shopping; augmented reality; virtual fitting; omnichannel; brand advocacy; product involvement

\section{Introduction}

The retail environment, which has been radically transformed over the past decade, has witnessed changes in retail business models and customer behaviors amid the popularization of smartphones and the emergence of new shopping channels such as online channels, mobile channels, and social media shopping (e.g., Facebook and Instagram shops) [1]. Recently, sales volumes generated from digital channels have been higher than those generated from offline channels [2], and, as people's dependence on mobile devices increases, $\mathrm{m}$-commerce is expected to account for $44 \%$ of all e-commerce transactions in 2024 [3]. Millennials and Gen Z, raised in a digital environment, are expected to be major contributors to the sales growth of the $\mathrm{m}$-commerce market. The boundaries between online and offline retail strategies are disappearing due to the changing shopping habits and preferences of the digital generation, who crave shopping experiences not only online but also in physical stores; retailers are adopting elastic strategies that integrate the two experiences [4]. Since mobile shopping is connected to customers in all contexts of their daily lives, mobile marketing strategies have the potential to increase customer engagement [5]. In the fashion industry, where offline retail stores are facing a crisis due to COVID-19, the introduction of new technologies such as augmented reality (AR) and mobile devices provides customers with a shopping experience that transcends boundaries between channels and organically connects various distribution channels.

In a digital environment, the information available to consumers is limited, as they cannot directly touch or try on a product. Companies undergoing a digital transformation 
are recognizing AR technology as a factor that can influence the customer journey in online and mobile retail environments [6,7]. The AR market is also showing growth in the fashion industry, attracting attention as a technology that can compensate for informational limitations and improve shopping experiences in the context of the COVID-19 pandemic, where offline activities are limited. Use of the virtual fitting (VF) app [8], which provides a simulation of virtual products based on the customer's body measurements, is expected to accelerate in line with the increasing trend of online shopping. By 2027, the global market size is expected to increase by USD 100 billion [9].

Augmented reality technology lies in the middle ground between a complete virtual world and reality [10]. In AR, a 3D-registered virtual reality is combined with reality and interacts in real time [11]. In other words, AR does not replace the real world but enriches it by integrating additional information into the customer's actual experience [12]. The VF service that applies AR provides customers with an experience different from that of previous media centered on personalized and immediate interactions and is having significant effects in the fields of marketing and advertising [13]. Burberry has provided a service that allows users to check their products on Google through an AR simulation [14]. British fashion brand ASOS has provided a "See My Fit" service in which customers can check the fit of clothes through AR models of various body types during the coronavirus period [15]. Augmented reality is increasingly being used to sell fashion products such as shoes, jewelry, and sunglasses, and it is recognized as an important tool in online shopping.

In the retail environment, atmospherics are factors that affect customers' shopping behavior [16]. Favorable feelings generated through a store's atmosphere have a positive effect on judgments of a product or service experience [17] and, eventually, on customers' shopping intention [18]. Research on the retail environment has been extended to the online shopping environment amid the development of information and communication technologies. Eroglu et al. [19] examined the effect of environmental stimulation on the behavioral responses of customers in an online shopping environment. It is important to induce customers to advocate for brands in the changed customer journey of the digital economy because the influence of the opinions of consumer communities on decision making in the digital environment has increased connectivity among customers [20]. Accordingly, this study expects that the new environment in which AR technology is being introduced into mobile apps will affect the relationship between the satisfaction perceived by customers, brand advocacy, and purchase intention. In addition, unlike previous studies on the application of new digital technologies, we explored individual characteristics related to the acceptance of innovative technology [21] and resistance to innovation [22]. This study focused on the mobile shopping situation and investigated the effect of individual customer characteristics such as fashion product involvement on the relationship between satisfaction with the VF experience and customer behavioral intentions in South Korea.

\section{Theoretical Background}

\subsection{VF Experience Satisfaction}

Satisfaction is the result of a cognitive evaluation conducted through comparisons between the expected level and the actual experience, as well as the result of subjective feelings [17]. For retail brands, customer satisfaction includes customer evaluations not only of the products but also of the brand image and the service experience [23]. Accordingly, this study defined VF experience satisfaction as an emotional result of the evaluation of VF services provided by retailers. Satisfaction is a predictor of behavioral variables such as repurchase intention, word of mouth (WOM), and loyalty [24,25] and is considered important in marketing. In the context of m-commerce, satisfaction was found to be a factor that directly affects loyalty [26].

Expected and actual appearances may differ because it is difficult to perfectly judge the suitability of a product in a mobile shopping environment [27]. Virtual fitting, applied based on the vividness and interaction of AR technology, decreases the gap between the expected and actual fit of clothing products [28]. This reduction can increase satisfaction 
after the consumption experience [29]. In addition, in VF, customers can adjust interactive content at a higher level, such as by freely controlling the size, color, and orientation of a virtually worn product $[30,31]$. Thus, AR experiences through personalized and multi-sensory stimuli enable interactions that immerse customers and lead to positive reactions [32].

Poushneh and Vasquez-Parraga [7] confirmed that the application of AR technology in the online shopping environment has a positive effect on satisfaction by enhancing customers' understanding of the product. An empirical study concluded that the embodied AR element of VF enhances customers' positive emotional responses such as pleasure and has a significant effect on customer satisfaction and purchase desire [33,34]. This study expected that customers who experienced a multi-sensory and realistic level of VF applied to mobile shopping apps would perceive high satisfaction, which was expected to affect behavioral variables such as customer brand advocacy and purchase intention.

\subsection{Brand Advocacy}

In marketing, brand advocacy is sometimes seen as WOM, wherein loyal customers active in the community disseminate positive opinions about the brand and persuade others to engage in it [20,35]. VanMeter et al. [36] confirmed that those who have an attachment to a brand on social media are likely to advocate for it, even if they are not an advocate offline, which increases the importance of customer loyalty in a digital environment. For example, Sneakerheads, a group that has an affinity for sneakers, forms a "Barbershop community culture", with whom it maintains a strong bond by sharing many stories, including those about the history of the brand and product information in an environment connected through social media and sneakers apps [37].

Customers feel as if they were in a relationship with the brands they consume, especially in the context of the relationship between retail brands and customers [38]. In the digital age, where customers are interconnected within the online community, advocacy is seen as a new definition of loyalty [20]. Brand loyalty [38], defined as a customer's psychological attachment to brand equity, reflects a customer's intention to continuously trade with a particular brand [39] and cannot simply be considered a repurchase [40]. Accordingly, loyalty is measured by variables such as conversion intention, repurchase intention, advocacy intention, and relationship expansion intention [39,41]. This study used brand advocacy as a variable to measure loyalty toward retailers according to the changed customer journey in the digital age.

Customers feel connected to a brand and have brand advocacy intentions when they are deeply engaged with it [42]; they may even show a willingness to help the brand [43]. Similarly, customers who are attached to a brand will resist negative information about it [44]. Therefore, this study considers brand advocacy as a concept that includes the spread of favorable WOM both offline and online and the process of coping with problems related to negative information.

Satisfaction is a major factor in determining repeat purchases and WOM, and is a typical antecedent of loyalty [29,45]. Park and Park [46] confirmed that the attributes of e-stores influenced satisfaction and that customers satisfied with e-stores continued to use and recommend the attributes to others, showing high loyalty. Since VF applied to the online environment stimulates communication between customers and satisfies their desire for self-expression, it is highly likely to be shared on social media [5]. In a similar vein, Sung [47] found in a study on the AR advertising effect of mobile apps that customers who were satisfied with AR advertising content not only formed purchase intentions but also voluntarily shared brand experiences with their social groups. Brand advocacy, formed voluntarily by individuals, has a significant influence on the purchase decisions of people in the same community based on trust [48]. In particular, SNS, the digital media customers use most often for eWOM [49], influences purchase decisions by allowing customers to exchange information and personal evaluations quickly and easily [50]. Therefore, this study proposed the following hypothesis: 
Hypothesis 1 (H1). High VF experience satisfaction has a positive impact on brand advocacy.

\subsection{Purchase Intention in the Omnichannel Context}

In an omnichannel environment, customers can experience a variety of channels simultaneously. Users freely utilize multiple channels depending on the advantages each one offers [51]. Therefore, the current shopping environment is a multiple-channel context, in which the customer experience occurs on multiple channels. Augmented reality as well as customer experience with AR affects purchase intention [7], the customer's tendency to purchase a specific product in the future [52]. E-tailers' interactive shopping experience through VF enhances customers' perceptions of previous purchases and increases their online purchase intentions by forming positive emotions such as visual satisfaction and pleasure [21]. Furthermore, the product and customer service information provided on websites was found to affect the intention to purchase online clothing [53].

In addition, VF-applied shopping apps can provide product-related content to customers and connect product purchases with stores by inducing customers' participation before they enter the store through the connection between customers and products [30]. By strengthening this connection before purchase [54], VF-applied shopping apps can induce more customers to visit retailers' offline channels. Digitalized shopping environments were found to differ in their influence on customer reactions depending on the type of fashion product involved; customers showed more interest when digital technology was applied to sports retail stores that focused on practical and functional values [55]. Furthermore, customers who have tried on sneakers virtually through AR-based VF can be induced to visit offline stores, and those who experience digital technology in retail stores that sell sports products are expected to have positive purchase intentions. Accordingly, this study expected that customers who had a positive VF experience in a mobile environment would show high purchase intentions in mobile apps and offline stores. Thus, the following hypotheses were proposed:

Hypothesis 2 (H2). High satisfaction with VF experience improves customers' purchase intention in mobile apps.

Hypothesis 3 (H3). High satisfaction with VF experience improves purchase intention in offline stores.

Augmented reality content also has strong potential in integrated marketing strategies that enhance online and offline experiences by applying digital information to the physical world [5]. In the shopping environment, where customers' experiences can be linked seamlessly across various channels, customer loyalty is not confined to only certain channels [56]. Beck and Crié [57] show that a VF app in a cross-channel context creates patronage for both the website and the physical store. This study built on this empirically verified positive effect and expanded into the omnichannel context to examine the influence of brand advocacy on mobile and offline purchase intentions after VF experience. The study also investigated the mediating role of brand advocacy in the relationship between VF experience satisfaction and purchase intention. Thus, the following were proposed:

Hypothesis 4 (H4). Brand advocacy formed after the VF experience has a positive impact on mobile purchase intentions.

Hypothesis 5 (H5). Brand advocacy formed after the VF experience has a positive effect on offline purchase intentions.

Hypothesis 6 (H6). VF experience satisfaction has a positive effect on mobile purchase intention through brand advocacy. 
Hypothesis 7 (H7). VF experience satisfaction has a positive effect on offline purchase intention through brand advocacy.

\subsection{Product Involvement}

Involvement is defined as "a person's perceived relevance of the object based on inherent needs, values, and interests". This concept has been applied to various contexts, such as products and purchasing decisions [58]. High involvement generally reflects high personal relevance [59]. Product involvement can be defined as the customer's interest in a specific product. Fashion products have generally been classified as highly involved [60]. This study focused on sports shoes as the fashion products presented in the stimulus, and the degree of product involvement was defined as the degree of an individual's interest in the sports shoes.

Degree of involvement generates differences in the formation of customer satisfaction [61]. Involvement, one of the many personal characteristics that define customers, affects the experiences and behaviors of customers shopping both offline and on the web [62]. In the online shopping environment, highly involved customers need detailed information regarding the properties or quality of a product [63], and customers with high involvement in products tend to have a high level of understanding of the information delivered during their shopping [64]. During online shopping, customers' information-processing and decision-making processes may differ depending on their degree of involvement with a specific product. Accordingly, this study considered the degree of involvement as a factor influencing the evaluation of mobile shopping apps.

Virtual fitting, which allows customers to try on virtual 3D products by reflecting their actual appearance, renders the shopping experience in the app more realistic by providing a higher level of product information through visual stimulation. The degree to which customers process information such as visual stimuli delivered in a retail environment affects their emotions and preferences [65]. Customers will have higher satisfaction with VF services, which is expected to strengthen the relationship between VF experience satisfaction and customer behavior by enhancing brand advocacy and purchase intention. Therefore, the following was proposed:

Hypothesis 8 (H8). The relationship between VF experience satisfaction, brand advocacy, and mobile and offline purchase intentions is stronger in the high involvement group.

Figure 1 presents the study's research model regarding how customer satisfaction with VF, a new environment created via mobile shopping apps, affects customers' behavioral intentions.

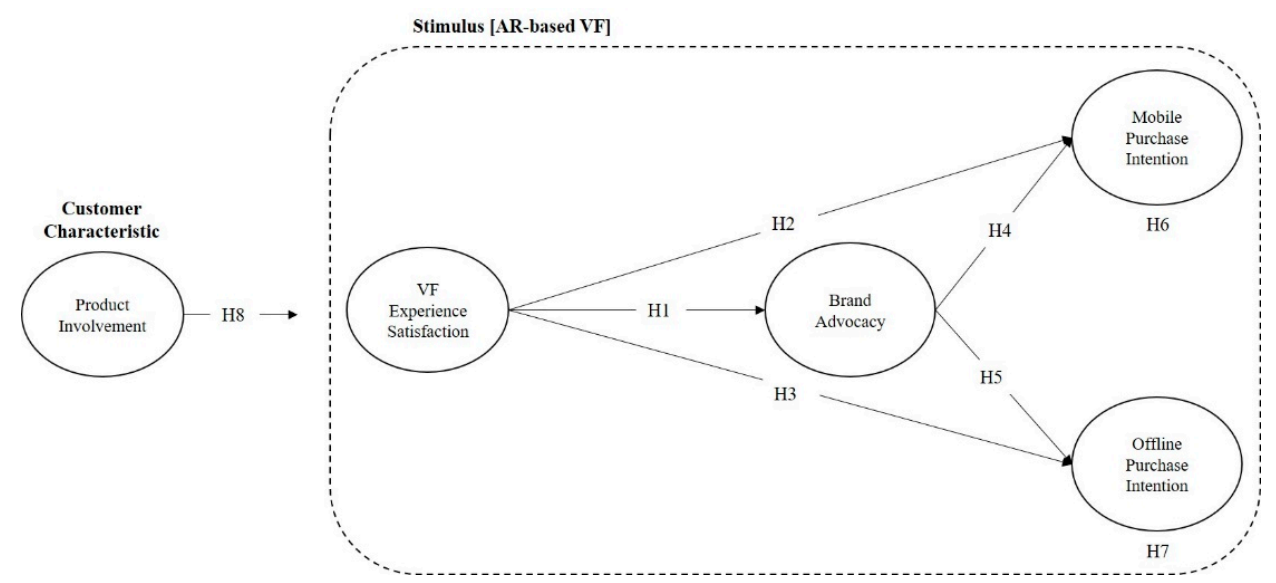

Figure 1. Research model. 


\section{Method}

\subsection{Stimulus}

This study ensured accuracy in the prediction of actual behavioral responses by presenting scenarios of shopping situations and a video using mobile VF as stimuli so that study participants could respond to the questionnaire. The shopping item in the video was a sports brand, which was selected because it is less affected by gender and age than other alternatives. Well-known sneakers brands $\left(\mathrm{N}^{*}\right.$ and $\left.\mathrm{A}^{*}\right)$ were used to increase the sense of a real shopping experience. A mock mobile app for the virtual shoe editing shop brand, "A Shop," was created for the research. The experience of the AR fitting service offered by "A Shop" was rendered in a video clip and used as a stimulus (see Figure 2).
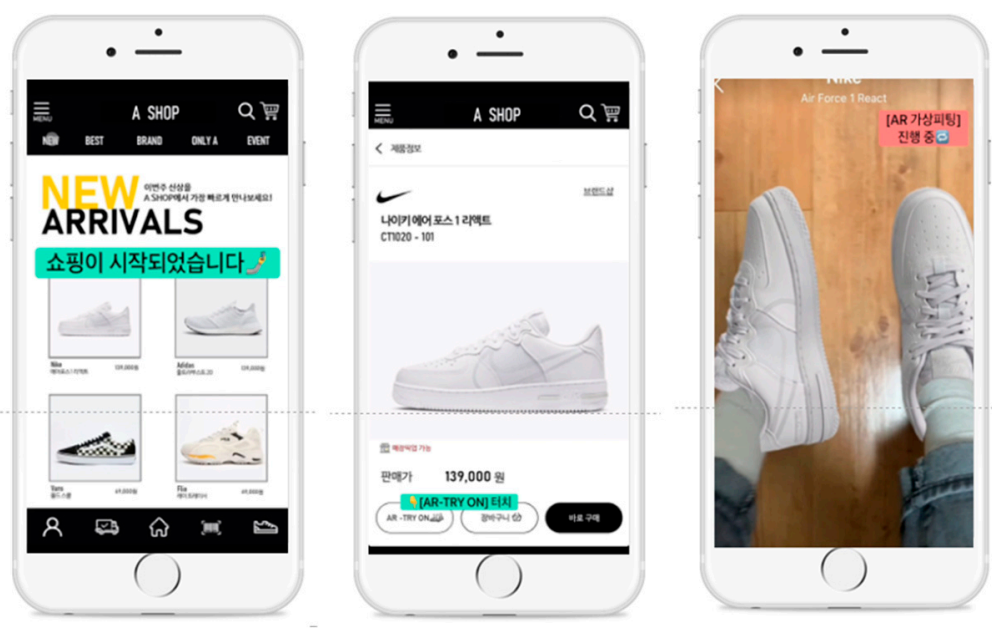

Figure 2. VF experience using "A Shop" mobile shopping app.

The study verified the suitability of the experimental stimulus and the participants' understanding of the questionnaire items through a preliminary survey on six men and women who majored in fashion and five non-majors in their 20s and 30s. The results revealed that the perceived interactivity $(M=5.70, S D=0.80)$ and perceived vividness $(M=5.89, S D=0.55)$ scores were an average of 5.70 or higher. Therefore, the stimulus was judged to be suitable (see Table 1).

Table 1. Results of testing the verification of the stimulus.

\begin{tabular}{cccc}
\hline & $\boldsymbol{N}$ & $\boldsymbol{M}$ & $\boldsymbol{S D}$ \\
\hline Perceived & 11 & 5.70 & 0.80 \\
interactivity & 11 & 5.89 & 0.55 \\
\hline Perceived vividness & & & \\
\hline
\end{tabular}

\subsection{Participants and Procedure}

The study participants were South Korean male and female customers in their 20s and 30s who had purchased sneakers in the past year, selected through a mobile survey conducted from 13 to 18 November 2020 by a specialized research organization. A total of 100 panel data were selected as valid samples and used for analysis, excluding responses that failed to correctly answer questions regarding the presented image. To minimize the influence of gender and age on the experimental results, each ratio was equally controlled, and the participants' AR experiences and SNS usage status (which could affect the results) were also identified (see Table 2). The average age of the participants was 29.5. The occupations of the participants varied; the most common occupation was office workers (41), followed by students (25), professionals (18), unemployed (11), and service industries (3). The most common average monthly expenditure on clothes was between KRW 100,000 or more and less than KRW 200,000 (43), followed by less than KRW 100,000 (28), more 
than KRW 200,000 (17), more than KRW 300,000 (12), and less than KRW 400,000 (3). It was found that $71 \%$ of respondents spent an average of less than KRW 200,000 per month on clothes. More than half of the participants (57\%) had previous AR experience, and most had social media accounts (94\%).

Table 2. Demographic statistics.

\begin{tabular}{|c|c|c|c|}
\hline & Frequency & & Frequency \\
\hline Gender & & Average clothing expenditure per month & \\
\hline Male & 50 & Less than $100,000 \mathrm{KRW}$ & 28 \\
\hline \multirow[t]{2}{*}{ Female } & 50 & 100,000-200,000 KRW & 43 \\
\hline & & $200,000-300,000 \mathrm{KRW}$ & 17 \\
\hline Age & & $300,000-400,000 \mathrm{KRW}$ & 9 \\
\hline $20-29$ & 50 & More than 400,000 KRW & 3 \\
\hline \multirow{2}{*}{$30-39$} & 50 & & \\
\hline & & Experience of AR & \\
\hline Occupation & & Yes & 57 \\
\hline Office worker & 41 & No & 43 \\
\hline Student & 25 & & \\
\hline Professional & 18 & Number of SNS accounts & \\
\hline Unemployed & 11 & Zero & 6 \\
\hline Sales service & 3 & 1 & 28 \\
\hline \multirow{2}{*}{ Others } & 2 & $2-3$ & 58 \\
\hline & & Over 4 & 8 \\
\hline
\end{tabular}

Note: $N=100$; percentage is the same as frequency.

To immerse the participants in the experiment, a shopping scenario at the virtual "A Shop" was presented after they had answered a question meant to evoke a recent experience of purchasing sneakers. In the shopping scenario, a participant who had purchased a product from "A Shop" offline, purchased the sneakers that he would normally wear on the retailer's mobile app. "A Shop" was presented as an omnichannel shop in which the distribution channels were connected. Participants who read the scenario responded to the questionnaire after an indirect shopping experience through a video of shopping using VF on a mobile app.

\subsection{Measurement}

The questionnaire was revised to fit the characteristics of the AR fitting experience study in the mobile app by referring to previous studies. Each question was measured on a 7-point Likert scale ranging from "not at all (1)" to "very much (7)" (see Table 3). The study measured VF experience satisfaction using three items adapted from Au et al. [66], and brand advocacy was measured using five items adapted from Fullerton [67], Kim et al. [43] and Sung [47]. Mobile and offline purchase intentions were found by Beck and Crié [57] to have high homogeneity (Cronbach's $\alpha>0.90$ ) in their measurement variables [68] and to thus constitute a single measurement item. For product involvement related to sneakers, five items were adapted from the Personal Involvement Inventory (PII) scale used by Zaichkowsky [69] and O'Cass [70] and were modified to fit the study. 
Table 3. Construct reliability and convergent validity.

\begin{tabular}{|c|c|c|c|c|c|}
\hline Construct & Items & Indicator Loading & Cronbach's $\alpha$ & CR & AVE \\
\hline $\begin{array}{l}\text { VF experience } \\
\text { satisfaction }\end{array}$ & $\begin{array}{l}\text { With the VF experience of this mobile app, I am: } \\
\text { Contented } \\
\text { Delighted } \\
\text { Satisfied }\end{array}$ & $\begin{array}{l}0.95 \\
0.95 \\
0.97 \\
\end{array}$ & 0.96 & 0.97 & 0.92 \\
\hline $\begin{array}{l}\text { Brand } \\
\text { advocacy }\end{array}$ & $\begin{array}{l}\text { I will say positive things about "A Shop" to other people. } \\
\text { I will defend "A Shop" when other people criticize it. } \\
\text { I would like to recommend "A Shop" to others who want to buy shoes. } \\
\text { I would like to share this VF experience with my friends on my SNS. } \\
\text { I would like to upload this VF experience on my SNS account. }\end{array}$ & $\begin{array}{l}0.81 \\
0.81 \\
0.90 \\
0.87 \\
0.80\end{array}$ & 0.90 & 0.92 & 0.70 \\
\hline $\begin{array}{l}\text { Mobile purchase } \\
\text { intention }\end{array}$ & I am willing to buy the product on this mobile app. & 1 & 1 & 1 & 1 \\
\hline $\begin{array}{l}\text { Offline purchase } \\
\text { intention }\end{array}$ & I am willing to visit the offline store and buy the product. & 1 & 1 & 1 & 1 \\
\hline
\end{tabular}

Note: $\mathrm{CR}=$ composite reliability, AVE = average variance extracted.

\subsection{Analysis}

This study constituted exploratory research that examined the effect of customers' VF experience satisfaction on their brand advocacy to investigate the relationship between purchase intentions in the mobile and offline channels in the multi-channel context. It was judged that an analysis using partial least squares structural equation modeling (PLS-SEM) was suitable for comparing the modulating effect of customers' personal characteristics in relation to the shopping environment [71]. Multi-group analysis (MGA) was performed after product involvement, a continuous control variable, was converted into a categorical variable using the average value.

The SPSS 25.0 program was used to perform frequency analysis, crossover analysis, and factor analysis on the data, and the Smart PLS 3.0 program was used to perform structural model analysis, hypothesis verification, and MGA.

\section{Results}

\subsection{Evaluation of Measurement and Structural Model}

Before evaluating the structural model in the PLS structural equation, the measurement model was verified by analyzing the reliability and validity of each latent variable. As shown in Table 3, the Cronbach's $\alpha$ and composite reliability (CR) values were both 0.9 or higher, indicating internal consistency between the measured variables. The outer loading value was found to be $0.83-0.97$, above the standard value, and the average variance extracted (AVE) value was above 0.70 , indicating concentration validity. Discriminant validity was confirmed by the Fornell-Larcker criterion and the heterotrait-monotrait ratio (HTMT). As shown in Table 4, the AVE squared value was found to be greater than the correlation coefficient with other latent variables [72], and the HTMT value was distributed between 0.32 and 0.83 , which is a value less than the baseline value of 0.85 [73].

Table 4. Discriminant validity (Fornell-Larcker criterion) and correlation between variables.

\begin{tabular}{ccccc}
\hline & SA & AV & MPI & OPI \\
\hline VFS & $0.96^{\text {a }}$ & & & \\
AV & $0.68^{* * *}$ & 0.84 & & \\
MPI & $0.82^{* * *}$ & $0.65^{* * *}$ & $0.32^{* *}$ & - \\
OPI & $0.34^{* *}$ & $0.42^{* * *}$ & 5.51 & 5.20 \\
M & 5.49 & 4.83 & 1.37 & 1.29 \\
SD & 1.31 & 1.24 & & \\
\hline Note: $^{* *} p<0.01^{* * *} p<0.001 ;$ VF experience satisfaction (VFS); Brand advocacy (AV); Mobile purchase intention
\end{tabular}

(MPI); Offline purchase intention (OPI). ${ }^{\mathrm{a}}$ : Bold numbers represent the square root of AVE for each construct.

To evaluate the suitability of the structural model, the values of $R^{2}$ (coefficient of determinant), $\mathrm{f}^{2}$ (effect size), and $\mathrm{Q}^{2}$ (predictive relevance) were checked. The results were confirmed to have a high explanatory power of $\sim 0.79$. $\mathrm{f}^{2}$ indicated a value of $0.07-1.22$ except between the customer satisfaction and offline purchase intention variables $\left(\mathrm{f}^{2}=0.00\right)$, 
confirming that it had a medium or higher effect size, and a $Q^{2}$ value greater than 0 for all potential variables, indicating a predictive fit. The variance inflation factor (VIF) value was 1.00 to 2.22 , confirming that there was no multicollinearity problem.

\subsection{Hypothesis Testing}

\subsubsection{Result of Main and Mediation Effects Test}

In this study, the significance and suitability of the path coefficients were verified through 5000 bootstrap resampling to identify the effect of VF experience satisfaction on brand advocacy, mobile purchase intention, and offline purchase intention. The results are presented in Figure 3 and Table 5.

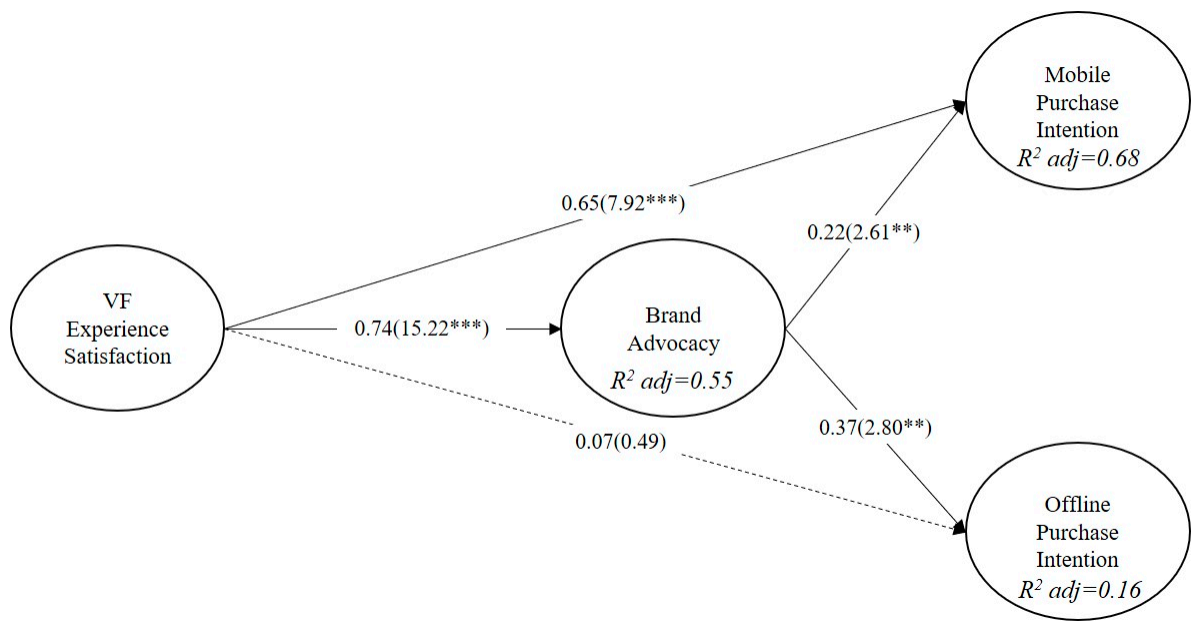

Figure 3. Results of PLS-SEM analysis. Note: ${ }^{* *} p<0.01,{ }^{* * *} p<0.001$; stimulus: AR-based VF.

Table 5. Result of structural equation modeling.

\begin{tabular}{cccccc}
\hline & Structural Model Paths & Path Coefficient & S.E. & $t$ & Result \\
\hline H1 & VF experience satisfaction $\rightarrow$ Brand advocacy & 0.74 & 0.05 & $14.91^{* * *}$ & Accepted \\
\hline H2 & VF experience satisfaction $\rightarrow$ Mobile purchase intention & 0.65 & 0.08 & $7.86^{* * *}$ & Accepted \\
\hline H3 & VF experience satisfaction $\rightarrow$ Offline purchase intention & 0.07 & 0.14 & 0.49 & Rejected \\
\hline H4 & Brand advocacy $\rightarrow$ Mobile purchase intention & 0.22 & 0.08 & $2.58^{* *}$ & Accepted \\
\hline H5 & Brand advocacy $\rightarrow$ Offline purchase intention & 0.37 & 0.13 & $2.77^{* *}$ & Accepted \\
\hline
\end{tabular}

Note: ${ }^{* *} p<0.01, * * * p<0.001$.

Satisfaction with the VF experience was found to have a positive effect on brand advocacy $(\beta=0.74, p<0.001)$ and mobile purchase intention $(\beta=0.65, p<0.001)$. Although both $\mathrm{H} 1$ and $\mathrm{H} 2$ were supported, $\mathrm{H} 3$ was rejected because VF experience satisfaction did not significantly affect offline purchase intention $(\beta=0.07, p>0.05)$. Brand advocacy was found to have a positive effect on both mobile purchase intention $(\beta=0.22, p<0.01)$ and offline purchase intention ( $\beta=0.37, p<0.01$ ); thus, $\mathrm{H} 4$ and $\mathrm{H} 5$ were both supported.

Table 6 shows the results for the mediating effect of brand advocacy on VF experience satisfaction and purchase intention. They indicate a partial mediating effect of brand advocacy in the relationship between VF experience satisfaction and mobile purchase intention $(\beta=0.16, p<0.01)$ and a complete mediating effect in the relationship between VF experience satisfaction and offline purchase intention $(\beta=0.27, p<0.001)$. Therefore, H6 and H7 were both supported. 
Table 6. Mediation effects of brand advocacy.

\begin{tabular}{lcccc}
\hline & Structural Model Paths & Path Coefficient & S.E. & Result \\
\hline H6 & $\begin{array}{c}\text { VF experience satisfaction } \rightarrow \text { Brand advocacy } \\
\rightarrow \text { Mobile purchase intention }\end{array}$ & 0.16 & 0.06 \\
\hline H7 & $\begin{array}{c}\text { VF experience satisfaction } \rightarrow \text { Brand advocacy } \\
\rightarrow \text { Offline purchase intention }\end{array}$ & 0.27 & 0.10 \\
\hline
\end{tabular}

Note: ${ }^{* *} p<0.01,{ }^{* * *} p<0.001$.

\subsubsection{Moderating Effects of Customer Characteristics}

To confirm the moderating effect of individual customer characteristics, an MGA was performed after the sample was divided into two groups: those with high and those with low involvement in sports shoes. Product involvement $(M=5.10, S D=1.10)$, a continuous variable, was converted into a categorical variable using the average value. The high involvement group had 49 people, and the low involvement group had 51; the minimum sample size $(<20)$ required by PLS-SEM was thus met according to the 10-fold rule [74].

Table 7 shows the hypothetical path significance of each group and the analysis results of the path difference between them. A difference among the groups appeared according to the degree of their involvement with sneakers; only the effect of VF experience satisfaction on offline purchase intention was statistically significant. Therefore, H8 was partially supported.

Table 7. Moderating effects of product involvement.

\begin{tabular}{cccc}
\hline Structural Model Paths & $\begin{array}{c}\text { High Involvement } \\
\boldsymbol{\beta}(\boldsymbol{t})\end{array}$ & $\begin{array}{c}\text { Low Involvement } \\
\boldsymbol{\beta}(\boldsymbol{t})\end{array}$ & $\begin{array}{c}\text { Difference of } \\
\text { Path Coefficient }^{\text {a }}(\boldsymbol{t})\end{array}$ \\
\hline VF experience satisfaction $\rightarrow$ Brand advocacy & $0.62\left(7.24^{* * *}\right)$ & $0.77\left(11.57^{* * *}\right)$ & $-0.15(-4.33)$ \\
\hline VF experience satisfaction $\rightarrow$ Mobile purchase intention & $0.64\left(6.14^{* * *}\right)$ & $0.60\left(3.87^{* * *}\right)$ & $0.05(2.27)$ \\
\hline VF experience satisfaction $\rightarrow$ Offline purchase intention & $-0.34\left(2.19^{*}\right)$ & $0.38(1.70)$ & $-0.72\left(0.49^{* * *}\right)$ \\
\hline Brand advocacy $\rightarrow$ Mobile purchase intention & $0.23\left(2.28^{*}\right)$ & $0.23(1.47)$ & $0.01(0.81)$ \\
\hline Brand advocacy $\rightarrow$ Offline purchase intention & $0.58\left(3.33^{* * *}\right)$ & $0.08(0.31)$ & $0.50(3.02)$ \\
\hline
\end{tabular}

Note: ${ }^{*} p<0.05,{ }^{* * *} p<0.001$; High involvement group: $N=49$; Low involvement group: $N=51$. ${ }^{\text {a }}$ : High involvement group-Low involvement group.

Specifically, significant results were found in all routes for the group with high involvement in running shoes. There was a negative effect of VF experience satisfaction ( $\beta=-0.34, p<0.05)$ on offline purchase intention, but brand advocacy $(\beta=0.58, p<0.001)$ had a positive effect, with a high level of significance probability. In the low involvement group, only the effects of VF experience satisfaction on brand advocacy $(\beta=0.77, p<0.001)$ and mobile purchase intention $(\beta=0.60, p<0.001)$ were significant.

Furthermore, VF experience satisfaction had a noticeable effect on brand advocacy $(\beta=-0.15)$, and brand advocacy had a noticeable effect on offline purchase intention ( $\beta=0.50)$ according to degree of product involvement; there was a difference between, but it was not statistically significant. A statistically significant difference was found only for the effect of VF experience satisfaction on offline purchase intention $(\beta=-0.72)$. A significantly negative influence was found for customers who were highly involved in the VF experience, contrary to the expectation that the relationship between VF experience satisfaction and behavioral intention would be strengthened.

\section{Discussion and Conclusions}

Digital transformation has emerged as an important issue upon which the survival of retailers depends. It is thus necessary to measure the impact and effectiveness of ARbased VF, which is being actively adopted by fashion retailers. This study investigated the relationship between satisfaction and brand advocacy after a VF experience and the influence of VF experience satisfaction and brand advocacy on purchase intention in two channels (mobile and offline) from an omnichannel point of view. 
The study revealed that satisfaction with AR-based VF experience has an important influence on the formation of brand advocacy and purchase intention in mobile apps. Consistent with previous studies, visual satisfaction through a realistic product simulation, such as fitting in an offline store, was found to improve purchase intention in the shopping channel the customer utilized [21]. Customers' personal experiences with VF on their smartphones can make their relationship with retailers more intimate, and customers who feel positive emotions such as satisfaction will advocate for a particular retail brand in their community. Given that brand advocacy can be measured as loyalty in the digital age [20], these results align with the fact that customers who are satisfied with e-stores tend to show high loyalty [46].

Additionally, we confirmed the influence of brand advocacy on purchase intentions in two retail shopping channels. Brand advocacy showed a partially mediating effect between VF experience satisfaction and mobile purchase intention, and it showed a complete mediating effect between VF experience satisfaction and offline purchase intention. In other words, customers who were satisfied with their use of VF, which improves product diagnostics and provides a pleasant shopping experience, showed a positive response to purchases on mobile apps without forming brand advocacy. In contrast, positive purchase intention was shown for offline channels only when customer actions were preceded by brand advocacy. This suggests that VF can provide customers with the level of product information they want and that connecting mobile experiences to offline stores is more effective when targeting advocates who are attached to the brand. These results are consistent with the those of Dacko [30], who found that AR-based content related to products can lead to product purchases in stores by strengthening the connection between customers and products and enhancing brand loyalty. A multi-group analysis was conducted to identify the customers for whom VF is most effective. The results confirmed that there was a significant difference in satisfaction and offline purchase intention between the high- and low-involvement groups. If a customer group that was interested in sports shoes was satisfied with the VF experience, they had positive purchase intentions for mobile shopping experiences but negative purchase intentions for offline purchases, contrary to expectations. Brand advocacy was found to have a positive effect on both mobile and offline purchase intentions. In contrast, in the customer group with relatively little interest in sports shoes, only the effect of satisfaction with VF experience on brand advocacy and mobile purchase intention was confirmed to be significant. Although VF experience satisfaction had a positive effect on offline purchase intention, it was not statistically significant. These results indicate that VF provided high-level information that was sufficient for making a purchase decision in a mobile environment for highly involved customers who had a high-level understanding of the information delivered during shopping. Thus, the higher the satisfaction of highly involved customers, the more negative were the reactions to offline purchases. However, as brand advocacy had a positive and significant influence on offline purchase intentions, the study found that even offline purchases were considered positively if a customer exhibited loyalty great enough to make them recommend the brand to others and be willing to defend it. These results indicate that targeting highly engaged customers would be the most effective way for retailers to enhance the integration of customers' online and offline purchasing experiences through VF.

This study has several implications. First, using a stimulus similar to the actual marketing environment confirmed that there is a significant relationship between a customer's emotional evaluation and behavioral intention in AR-based VF. The study set purchase intention in two shopping channels - mobile and offline-as a variable, and each route was examined in the context of a multi-channel environment in which shopping channels were diversified. This suggests that the degree of VF experience satisfaction and brand advocacy may be important determinants for an organic connection between multiple channels through the VF experience. Second, the results concerning the effect of the shopping environment, in which VF showed different effects according to the product involvement, suggest that purchase intentions appeared in both mobile and offline channels if brand 
advocacy had already been formed. Thus, it might be most effective to induce customer participation in various channels by integrating online and offline experiences and by providing personalized services such as VF to customers who are already interested in the product.

The study has some limitations. To minimize the influence of product brand preferences, two brands with similar levels of awareness and preferences were used as stimuli after a preliminary investigation. In addition, future research should investigate whether AR experiences, including previous VF experiences, can affect satisfaction. Moreover, customers' shopping patterns, which have changed due to the COVID-19 pandemic, were not sufficiently considered. Furthermore, the sample was limited to subjects in their 20s and 30s, who are familiar with the use of digital devices; however, mobile shopping among people in their 40s and 50s has increased due to social distancing protocols. Thus, future studies should also investigate the purchasing behavior of this age group. Finally, this study examined customers' reactions to VF contents among AR technology-based services in the fashion industry. Future studies should conduct a comparative analysis with other contents based on AR technology. Expanded research on the AR shopping environment could analyze and compare ways of reinforcing the shopping experience of customers based on individual characteristics and identify which method is most effective.

Author Contributions: Conceptualization, H.-L.R. and K.-H.L.; methodology, H.-L.R. and K.-H.L.; software, H.-L.R.; writing—original draft preparation, H.-L.R. and K.-H.L.; writing-review and editing, K.-H.L.; visualization, H.-L.R.; supervision, K.-H.L. All authors have read and agreed to the published version of the manuscript.

Funding: This research received no external funding.

Institutional Review Board Statement: Not applicable.

Informed Consent Statement: Informed consent was obtained from all subjects involved in the study.

Data Availability Statement: Not applicable.

Conflicts of Interest: The authors declare no conflict of interest.

\section{References}

1. Verhoef, P.C.; Kannan, P.K.; Inman, J.J. From multi-channel retailing to omni-channel retailing: Introduction to the special issue on multi-channel retailing. J. Retail. 2015, 91, 174-181. [CrossRef]

2. eMarketer. US Omnichannel Retail Statpack 2018: Marketer and Consumer Trend. Available online: https://on.emarketer.com/ rs/867-SLG-901/images/eMarketer_US_Omnichannel_Retail_StatPack_2018_3.pdf (accessed on 4 December 2020).

3. Meloa, A. Rise of M-Commerce: Mobile Ecommerce Shopping Stats \& Trends in 2021. Available online: https://www. businessinsider.com/mobile-commerce-shopping-trends-stats (accessed on 31 December 2020).

4. Tan, O. What Divide? Online and Offline Shopping Experiences Are Already Merged. Available online: https:// www.digitalcommerce360.com/2018/08/22/what-divide-online-and-offline-shopping-experiences-are-already-merged/ (accessed on 31 December 2020).

5. Scholz, J.; Smith, A.N. Augmented reality: Designing immersive experiences that maximize customer engagement. Bus. Horiz. 2016, 59, 149-161. [CrossRef]

6. Javornik, A. Augmented reality: Research agenda for studying the impact of its media characteristics on customer behaviour. J. Retail. Consum. Serv. 2016, 30, 252-261. [CrossRef]

7. Poushneh, A.; Vasquez-Parraga, A.Z. Discernible impact of augmented reality on retail customer's experience, satisfaction and willingness to buy. J. Retail. Consum. Serv. 2017, 34, 229-234. [CrossRef]

8. Blazquez, M. Fashion shopping in multichannel retail: The role of technology in enhancing the customer experience. Int. J. Electron. Commer. 2014, 18, 97-116. [CrossRef]

9. Fortune Business Insights. Virtual Fitting Room Market Size, Share and COVID-19 Impact Analysis, by Component (Hardware, Software, and Services), by Services (Integration, Support and Maintenance, and Consulting), by Application (Apparel, Jewelry and Watches, and Others), by End User (Physical Stores and Virtual Store) and Regional Forecast, $2020-2027$. Available online: https://www.fortunebusinessinsights.com/industry-reports/virtual-fitting-room-VFR-market-100322 (accessed on 15 February 2021).

10. Milgram, P.; Kenshino, F. A taxonomy of mixed reality visual display. IEICE Trans. Inf. Syst. 1994, 77, 1321-1329.

11. Azuma, R.T. A survey of augmented reality. Presence Teleoperators Virtual Environ. 1997, 6, 355-385. [CrossRef]

12. Ma, J.Y.; Choi, J.S. The virtuality and reality of augmented reality. J. Multimed. 2007, 2, 32-37. [CrossRef] 
13. Kim, K.Y.; Jung, W. A study on the impact of perceived characteristics of augmented reality (AR) services on user satisfaction and intention to use. Glob. Bus. Adm. Rev. 2020, 17, 187-211. [CrossRef]

14. Hughes, H. Burberry Launches AR Tool with Google. Available online: https://fashionunited.uk/news/fashion/burberrylaunches-ar-tool-with-google/2020022547684 (accessed on 25 February 2021).

15. Digital. Asos Launches AR Fitting Tool for Online Shoppers. Available online: https://www.borndigital.com/2020/05/13/asoslaunches-ar-fitting-tool-for-online-shoppers (accessed on 25 February 2021).

16. Kotler, P. Atmospherics as a marketing tool. J. Retail. 1973, 49, 48-64.

17. Westbrook, R.A. Intrapersonal affective influences on customer satisfaction with products. J. Consum. Res. 1980, 7, 49-54. [CrossRef]

18. Dawson, S.; Bloch, P.H.; Ridgway, N.M. Shopping motives, emotional states, and retail outcomes. J. Retail. 1990, 66, 408-427.

19. Eroglu, S.A.; Machleit, K.A.; Davis, L.M. Atmospheric qualities of online retailing: A conceptual model and implications. J. Bus. Res. 2001, 54, 177-184. [CrossRef]

20. Kotler, P.; Kartajaya, H.; Setiawan, I. Marketing 4.0: Moving from Traditional to Digital; John Wiley \& Sons. Inc.: Hoboken, NJ, USA, 2017; pp. 15-17.

21. Huang, T.L.; Liao, S. A model of acceptance of augmented-reality interactive technology: The moderating role of cognitive innovativeness. Electron. Commer. Res. 2015, 15, 269-295. [CrossRef]

22. Ju, N.; Lee, K.-H. Customer resistance to innovation: Smart clothing. Fash. Text. 2020, 7, 21. [CrossRef]

23. Kozinets, R.; Sherry, J.; DeBerry-Spence, B.; Duhachek, A.; Nuttavuthisit, K.; Storm, D. Themed flagship brand stores in the new millennium: Theory, practice, prospects. J. Retail. 2002, 78, 17-29. [CrossRef]

24. Eggert, A.; Ulaga, W. Customer perceived value: A substitute for satisfaction in business markets? J. Bus. Ind. Mark. 2002, 17, 107-118. [CrossRef]

25. Fornell, C.; Johnson, M.D.; Anderson, E.W.; Cha, J.; Bryant, B.E. The American customer satisfaction index: Nature, purpose, and findings. J. Mark. 1996, 60, 7-18. [CrossRef]

26. Lin, H.H.; Wang, Y.S. An examination of the determinants of customer loyalty in mobile commerce contexts. Inf. Manag. 2006, 43, 271-282. [CrossRef]

27. Rosa, J.A.; Garbarino, E.C.; Malter, A.J. Keeping the body in mind: The influence of body esteem and body boundary aberration on consumer beliefs and purchase intentions. J. Consum. Psychol. 2006, 16, 79-91. [CrossRef]

28. Jiang, Z.; Benbasat, I. Investigating the influence of the functional mechanisms of online product presentations. Inf. Syst. Res. 2007, 18, 454-470. [CrossRef]

29. Yang, S.; Xiong, G. Try it on! Contingency effects of virtual fitting rooms. Manag. Inf. Syst. 2019, 36, 789-822. [CrossRef]

30. Dacko, S.G. Enabling smart retail settings via mobile augmented reality shopping apps. Technol. Forecast. Soc. Chang. 2017, 124, 243-256. [CrossRef]

31. Huang, T.L. Creating a commercially compelling smart service encounter. Serv. Bus. 2018, 12, 357-377. [CrossRef]

32. Fiore, A.M.; Jin, H.J.; Kim, J. For fun and profit: Hedonic value from image interactivity and responses toward an online store. Psychol. Mark. 2005, 22, 669-694. [CrossRef]

33. So, J.I.; Kim, S. The effects of augmented reality fashion application on pleasure, satisfaction and behavioral intention. Res. J. Costume Cult. 2013, 21, 810-826. [CrossRef]

34. Watson, A.; Alexander, B.; Salavati, L. The impact of experiential augmented reality applications on fashion purchase intention. Int. J. Retail. Distrib. Manag. 2018, 48, 433-451. [CrossRef]

35. Matzler, K.; Pichler, E.A.; Hemetsberger, A. Who is spreading the word? The positive influence of extraversion on customer passion and brand evangelism. Mark. Theory Appl. 2007, 18, 25-32.

36. VanMeter, R.; Syrdal, H.A.; Powell-Mantel, S.; Grisaffe, D.B.; Nesson, E.T. Don't just “Like” me, promote me: How attachment and attitude influence brand related behaviors on social media. J. Interact. Mark. 2018, 43, 83-97. [CrossRef]

37. Matthews, D.; Cryer-Coupet, Q.; Degirmencioglu, N. I wear, therefore I am: Investigating sneakerhead culture, social identity, and brand preference among men. Fash. Text. 2021, 8, 1-13. [CrossRef]

38. Fournier, S. Customers and their brands: Developing relationship theory in customer research. J. Consum. Res. 1998, 24, 343-373. [CrossRef]

39. Zeithaml, V.; Berry, L.; Parasuraman, A. The behavioral consequences of service quality. J. Mark. 1996, 60, 31-46. [CrossRef]

40. Dick, P.; Basu, K. Customer loyalty: Toward and integrated conceptual framework. Acad. Mark. Sci. Rev. 1994, 22, 99-114. [CrossRef]

41. Fullerton, G.; Taylor, S. Mediating, interactive and non-linear effects in service quality and satisfaction with services research. Can. J. Adm. Sci. 2002, 19, 124-136. [CrossRef]

42. Bilro, R.G.; Loureiro, S.M.C.; Ali, F. The role of website stimuli of experience on engagement and brand advocacy. J. Hosp. Tour. Technol. 2018, 9, 204-222. [CrossRef]

43. Kim, M.S.; Shin, D.J.; Koo, D.W. The influence of perceived service fairness on brand trust, brand experience and brand citizenship behavior. Int. J. Contemp. Hosp. Manag. 2018, 30, 2603-2621. [CrossRef]

44. Batra, R.; Ahuvia, A.; Bagozzi, R.P. Brand love. J. Mark. 2012, 76, 1-16. [CrossRef]

45. Anderson, R.E.; Srinivasan, S.S. E-satisfaction and e-loyalty: A contingency framework. Psychol. Mark. 2003, 20, 123-138. [CrossRef] 
46. Park, S.K.; Park, Y.B. A study on the effects of e-store attributions on web site loyalty. J. Glob. Mark. 2005, 15, 21-39. [CrossRef]

47. Sung, E.C. The effects of augmented reality mobile app advertising: Viral marketing via shared social experience. J. Bus. Res. 2021, 122, 75-87. [CrossRef]

48. Keller, E. Unleashing the power of word of mouth: Creating brand advocacy to drive growth. J. Advert. Res. 2007, 47, 448-452. [CrossRef]

49. Chu, S.C.; Kim, Y. Determinants of customer engagement in electronic word-of-mouth (eWOM) in social networking sites. Int. J. Advert. 2011, 30, 47-75. [CrossRef]

50. Graham, J.; Havlena, W. Finding the "missing link": Advertising's impact on word of mouth, web searches, and site visits. J. Advert. Res. 2007, 47, 427-435. [CrossRef]

51. Verhoef, P.C.; Neslin, S.A.; Vroomen, B. Multichannel customer management: Understanding the research-shopper phenomenon. Int. J. Mark. 2007, 24, 129-148. [CrossRef]

52. Morrison, D.G. Purchase intentions and purchase behavior. J. Mark. 1979, 43, 65-74. [CrossRef]

53. Kim, J.-H.; Lennon, S.J. Information available on a web site: Effects on customers' shopping outcomes. J. Fash. Mark. Manag. 2010, 14, 247-262. [CrossRef]

54. Singh, M.; Singh, M.P. Augmented reality interfaces. IEEE Internet Comput. 2013, 17, 66-70. [CrossRef]

55. Kim, H.Y.; Lee, Y.; Jung, Y.J. Digital atmosphere of fashion retail stores. Fash. Text. 2020, 7, 1-17. [CrossRef]

56. Lee, M.; Lee, Y. Effects of customer experience on retailer loyalty and performance in an omni-channel environment: Comparison between department stores and discount stores. Korean Manag. Rev. 2019, 48, 211-241. [CrossRef]

57. Beck, M.; Crié, D. I virtually try it ... I want it! Virtual Fitting Room: A tool to increase on-line and offline exploratory behavior, patronage and purchase intentions. J. Retail. Consum. Serv. 2018, 40, 279-286. [CrossRef]

58. Zaichkowsky, J.L. Measuring the involvement construct. J. Consum. Res. 1985, 12, 341-352. [CrossRef]

59. Greenwald, A.G.; Leavitt, C. Audience involvement in advertising: Four levels. J. Consum. Res. 1984, 11, 581-592. [CrossRef]

60. Cho, Y.; Seo, S. A study on the buying behavior of fashion products in the group buying type of social commerce: Focused on shopping value, attitude, purchase intention, and clothing involvement. J. Korean Soc. Costume 2012, 62, 134-148. [CrossRef]

61. Suh, J.C.; Youjae, Y. When brand attitudes affect the customer satisfaction-loyalty relation: The moderating role of product involvement. J. Consum. Psychol. 2006, 16, 145-155. [CrossRef]

62. Novak, T.P.; Hoffman, D.L.; Yung, Y.F. Measuring the customer experience in online environments: A structural modeling approach. Mark. Sci. 2000, 19, 22-42. [CrossRef]

63. McGaughey, R.E.; Mason, K.H. The Internet as a marketing tool. J. Mark. Theory Pract. 1998, 6, 1-11. [CrossRef]

64. Gordon, M.E.; McKeage, K.; Fox, M.A. Relationship marketing effectiveness: The role of involvement. Psychol. Mark. 1998, 15, 443-459. [CrossRef]

65. Orth, U.R.; Wirtz, J. Customer processing of interior service environments: The interplay among visual complexity, processing fluency, and attractiveness. J. Serv. Res. 2014, 17, 296-309. [CrossRef]

66. Au, N.; Ngai, E.W.; Cheng, T.E. Extending the understanding of end user information systems satisfaction formation: An equitable needs fulfillment model approach. MIS Q. 2008, 43-66. [CrossRef]

67. Fullerton, G. The impact of brand commitment on loyalty to retail service brands. Can. J. Adm. Sci. 2005, 22, 97-110. [CrossRef]

68. Diamantopoulos, A.; Sarstedt, M.; Fuchs, C.; Wilczynski, P.; Kaiser, S. Guidelines for choosing between multi-item and single-item scales for construct measurement: A predictive validity perspective. J. Acad. Mark. Sci. 2012, 40, 434-449. [CrossRef]

69. Zaichkowsky, J.L. The personal involvement inventory: Reduction, revision, and application to advertising. J. Advert. 1994, 23, 59-70. [CrossRef]

70. O'Cass, A. An assessment of customers product, purchase decision, advertising and consumption involvement in fashion clothing. J. Econ. Psychol. 2000, 21, 545-576. [CrossRef]

71. Fornell, C.; Bookstein, F.L. Two structural equation models: LISREL and PLS applied to consumer exit-voice theory. J. Mark. Res. 1982, 19, 440-452. [CrossRef]

72. Fornell, C.; Larcker, D.F. Evaluating structural equation models with unobservable variables and measurement error. J. Mark. Res. 1981, 18, 39-50. [CrossRef]

73. Henseler, J.; Ringle, C.M.; Sarstedt, M. A new criterion for assessing discriminant validity in variance based structural equation modeling. Acad. Mark. Sci. Rev. 2015, 43, 115-135. [CrossRef]

74. Hair, J.F.; Sarstedt, M.; Hopkins, L.; Kuppelwieser, V.G. Partial least squares structural equation modeling (PLS-SEM): An emerging tool in business research. Eur. Bus. Rev. 2014, 26, 106-121. [CrossRef] 